\title{
Cytokines and soluble CD14 in breast milk in relation with atopic manifestations in mother and infant (KOALA Study)
}

Citation for published version (APA):

Snijders, B. E., Damoiseaux, J. G. M. C., Penders, J., Kummeling, I., Stelma, F. F., Van Ree, R., van den Brandt, P. A., \& Thijs, C. (2006). Cytokines and soluble CD14 in breast milk in relation with atopic manifestations in mother and infant (KOALA Study). Clinical and Experimental Allergy, 36(12), 1609-1615. https://doi.org/10.1111/j.1365-2222.2006.02613.x

Document status and date:

Published: 01/01/2006

DOI:

10.1111/j.1365-2222.2006.02613.x

Document Version:

Publisher's PDF, also known as Version of record

\section{Please check the document version of this publication:}

- A submitted manuscript is the version of the article upon submission and before peer-review. There can be important differences between the submitted version and the official published version of record. People interested in the research are advised to contact the author for the final version of the publication, or visit the DOI to the publisher's website.

- The final author version and the galley proof are versions of the publication after peer review.

- The final published version features the final layout of the paper including the volume, issue and page numbers.

Link to publication

\footnotetext{
General rights rights.

- You may freely distribute the URL identifying the publication in the public portal. please follow below link for the End User Agreement:

www.umlib.nl/taverne-license

Take down policy

If you believe that this document breaches copyright please contact us at:

repository@maastrichtuniversity.nl

providing details and we will investigate your claim.
}

Copyright and moral rights for the publications made accessible in the public portal are retained by the authors and/or other copyright owners and it is a condition of accessing publications that users recognise and abide by the legal requirements associated with these

- Users may download and print one copy of any publication from the public portal for the purpose of private study or research.

- You may not further distribute the material or use it for any profit-making activity or commercial gain

If the publication is distributed under the terms of Article $25 \mathrm{fa}$ of the Dutch Copyright Act, indicated by the "Taverne" license above, 


\title{
Cytokines and soluble CD14 in breast milk in relation with atopic manifestations in mother and infant (KOALA Study)
}

\author{
B. E. P. Snijders*, J. G. M. C. Damoiseaux ${ }^{\dagger}$, J. Penders ${ }^{\ddagger}$, I. Kummeling* ${ }^{*}$ F. F. Stelma ${ }^{\S}$, R. van Ree ${ }^{\ddagger}$ P. A. van den Brandt ${ }^{* \ddagger}$ and C. Thijs $^{* \ddagger}$ \\ * Care and Public Health Research Institute (CAPHRI), Department of Epidemiology, Maastricht University, Maastricht, The Netherlands, ${ }^{\dagger}$ Department of Clinical and \\ Experimental Immunology, University Hospital Maastricht, Maastricht, The Netherlands, ${ }^{\ddagger}$ Nutrition and Toxicology Research Institute Maastricht (NUTRIM), \\ Department of Epidemiology, Maastricht, The Netherlands, ${ }^{\S}$ Department of Medical Microbiology, University Hospital Maastricht, Maastricht, The Netherlands and \\ "Department of Experimental Immunology, Academic Medical Center, Amsterdam, The Netherlands
}

\section{Clinical and Experimental Allergy}

Correspondence:

Bianca E. P. Snijders, Department of Epidemiology, Maastricht University, PO Box 616, 6200 MD, Maastricht, The Netherlands.

E-mail:BEP.Snijders@EPID.unimaas.nl

\begin{abstract}
Summary
Background Conflicting evidence exists concerning the protective role of breastfeeding in allergy and atopic disease aetiology. Breast milk contains biologically active molecules influencing the innate immune system of newborns.

Objective We aim to assess whether cytokines (TGF- $\beta 1$, IL-10 and IL-12) and soluble CD14 (sCD14) in breast milk are influenced by maternal atopic constitution and modify the development of atopic manifestations in infants.

Methods Milk samples were collected at 1 month post-partum of 315 lactating mothers participating in the ongoing KOALA Birth Cohort Study. The cytokines and SCD14 were analysed by ELISA in the aqueous fraction. We compared the concentrations of cytokines and sCD14 in breast milk between mothers with and without an allergic history and also with and without allergic sensitization (specific IgE). Associations of cytokines and SCD14 with the development of eczema, wheezing in the first 2 years of life and allergic sensitization of infants at the age of 2 years were analysed by multivariate logistic regression analyses to correct for confounders.

Results We found higher SCD14 levels in mothers with a positive vs. negative allergic history (7.6 vs. $7.0 \mu \mathrm{g} / \mathrm{mL} ; P=0.04$ ) and in mothers who were sensitized vs. non-sensitized (7.8 vs. 7.1 $\mu \mathrm{g} / \mathrm{mL} ; P=0.03$ ). None of the studied immune factors were associated with infant's atopic outcomes. IL-10 was not detected above the detection limit of $0.2 \mathrm{pg} / \mathrm{mL}$.

Conclusion Taking together the results of the present and previous studies, we conclude that there is no convincing evidence for a relation between TGF- $\beta 1$, sCD14, IL-10 or IL-12 in breast milk and atopic manifestations in infants.
\end{abstract}

Keywords cytokines, eczema, human milk, immunoglobulin E, soluble CD14

Submitted 23 June 2006; revised 4 August 2006; accepted 20 September 2006

\section{Introduction}

Atopic diseases such as atopic eczema, allergic rhinitis and allergic asthma have increased in the developed world during recent decades [1]. Breastfeeding has been considered to afford protection against atopic disorders. Protection may be conveyed by biologically active molecules that are present in human milk such as cytokines, chemokines, hormones, growth factors, secretory antibodies and essential fatty acids [2, 3]. Through several mechanisms, immune-modulating factors in human milk can actively stimulate the newborn's immune system, which is rapidly maturing during the first years of life [4]. In the current study, we focus on four immune factors [TGF- $\beta 1$, IL-10, IL-12 and soluble CD14 (sCD14)] that may influence the innate immune system.

TGF- $\beta 1$ and IL-10 are anti-inflammatory cytokines produced by several cell types, including regulatory $\mathrm{T}$ cells, which are currently in the focus of allergy and asthma research [5]. Regulatory $\mathrm{T}$ cells suppress both T-helper type-1 (Th1)- and Th2-mediated immune responses [6] and are thought to play a role in the development of allergic disease [7]. Especially, TGF- $\beta 1$ is an abundant cytokine in human milk [8]. Oddy et al. [9] demonstrated a positive association between low concentrations of TGF- $\beta 1$ in human milk and infant wheezing. 
Human milk also contains IL-12 and the soluble form of CD14 (sCD14). Both are lipopolysaccharide (LPS) [10]-associated immune factors that promote Th1 development, thereby preventing excessive IgE production and allergic inflammation [11]. CD14 is an innate immune receptor for LPS, a component of gram-negative bacterial cell walls [12]. The complex interplay between CD14, toll-like receptor (TLR) 4 and MD-2 is responsible for recognition of LPS [13]. Subsequently, intracellular signalling results in secretion of IL-12. An association was found between reduced sCD14 levels in breast milk and a diagnosis of eczema in children aged 6 months [14]. Recently, increased levels of sCD14 were found to be associated with a lower incidence of doctor's diagnosed asthma at the age of 2 years, especially in children of mothers without a history of atopic diseases [15]. Also, a deficit of IL-12 production was proposed to occur in atopic individuals [11].

There are two possible explanations for the relation between levels of immune factors in breast milk and the development of atopy in the infant: first, maternal atopic constitution (genetic or acquired) determines levels of cytokines in breast milk and infant's atopy by separate mechanisms; second, immune factors have a direct effect on mucosal immunity in the child.

This study had two objectives. First, we aimed to investigate whether the mother's atopic constitution influences milk levels of TGF- $\beta 1$, IL-10, IL- 12 and sCD14. Second, we examined whether these immune factors are associated with the development of infant's atopy (eczema, wheezing) in the first 2 years of life and allergic sensitization at age 2 .

\section{Methods}

\section{Design}

This study is part of the KOALA Birth Cohort Study $(N=2834)$, an ongoing prospective birth cohort study in the Netherlands. The design of the study has been described, in detail, elsewhere [16]. Briefly, we recruited participants with diverse lifestyles (conventional and alternative) at 34 weeks of gestation. Pregnant women with a conventional lifestyle $(n=2343)$ were recruited from an ongoing prospective cohort study on pregnancyrelated pelvic girdle pain in the Netherlands. Additionally, pregnant women with an alternative lifestyle $(n=491)$ were recruited through several 'alternative' channels: organic food shops, anthroposophic doctors and midwifes, Steiner Schools and magazines. During the first 2 years post-partum, information on breastfeeding, atopic outcomes and their determinants was collected for all members of the cohort by repeated questionnaires at 3, 7, 12 and 24 months. During home visits at 34-36 weeks of gestation, maternal venous blood was collected. From
October 2002, we started recruiting participants for breast milk sampling by asking pregnant mothers who intended to start breastfeeding to consent for breast milk collection. This resulted in breast milk being sampled in 315 breastfeeding mothers between December 2002 and September 2003, including a short questionnaire at the time of breast milk collection (1 month post-partum). The study (including biosampling) was approved by the medical ethics committee of the Maastricht University.

\section{Collection and processing of breast milk}

Mothers received a sterile $50 \mathrm{~mL}$ tube (Cellstar PP-test tubes, Greiner bio-one, Kremsmünster, Austria) and were instructed to collect the milk sample in the morning, before breastfeeding their child, from the contra-lateral breast (since the last feeding) and to keep the tube in the refrigerator $\left( \pm 4{ }^{\circ} \mathrm{C}\right)$ until it was collected by one of the researchers. If the mother was not able to collect the milk sample by herself (with or without a pumping regimen), an electric breast pump (Medela, Baar, Switzerland) was used with the help of one of the researchers (within the same day). During transport, the milk samples were stored in a cooler (Coleman Company Inc., Breda, the Netherlands) on packed ice $\left( \pm 4^{\circ} \mathrm{C}\right)$ until processing on the same day. The sample was centrifuged ( $400 \mathrm{~g}, 12 \mathrm{~min}$, no brake, $\left.4{ }^{\circ} \mathrm{C}\right)$ to separate the lipid and aqueous fraction. The lipid layer was trimmed off with a pipette and released in plastic storage vials (Sarstedt, Nümbrecht, Germany). The aqueous fraction was poured in other vials with another pipette. The remaining debris was not used to avoid contamination with cell fragments. All fractions were stored at $-80^{\circ} \mathrm{C}$ in the European Biobank, Maastricht.

\section{Enzyme linked immunosorbent assays in breast milk}

Quantitative colorimetric cytokine ELISA kits were used to assess the concentrations of TGF- $\beta 1$, sCD14 (R\&D Systems Europe Ltd., Abingdon, UK), IL-10 and IL-12 (Biosource Int., Camarillo, CA, USA) in human aqueous milk fractions according to the manufacturer's instructions. The aqueous milk fractions were assayed at dilution factors of 1.4 for TGF- $\beta 1$ and 2000 for sCD14. The minimum detectable dose of TGF- $\beta 1$ and sCD14 was $7 \mathrm{pg} / \mathrm{mL}$ and $125 \mathrm{pg} / \mathrm{mL}$, respectively. For the activation of latent TGF- $\beta 1$ to the active form, a standard activation procedure was used. Briefly, $0.1 \mathrm{~mL} 1 \mathrm{~m} \mathrm{HCl}$ was added to $0.5 \mathrm{~mL}$ aqueous milk fraction and subsequently mixed to incubate for $10 \mathrm{~min}$ at room temperature. Neutralization of the acidified milk sample was performed by adding $0.1 \mathrm{~mL} 1.2 \mathrm{M} \mathrm{NaOH} / 0.5 \mathrm{M}$ 4-(2-hydroxyethyl)-1-piperazine-ethanesulfonic acid. Undiluted aqueous milk fractions were used to determine the IL-10 and IL-12 concentrations. The minimum detectable dose was $0.2 \mathrm{pg} / \mathrm{mL}$ for IL-10 and $0.8 \mathrm{pg} / \mathrm{mL}$ for IL-12. All ELISA assays were performed in duplicate. We conducted 
a pilot study for all parameters. We could not detect IL-10 concentrations in our pilot study $(n=16)$.

\section{Determination of maternal and infant's total and specific Immunoglobulin E}

Maternal venous blood samples were obtained during a home visit at 34-36 weeks of gestation. Serum samples were analysed for total IgE levels as described earlier [17, 18]. For values $<150 \mathrm{IU} / \mathrm{mL}$ a sandwich RIA was used [17], and for values $>150 \mathrm{IU} / \mathrm{mL}$ a competitive RIA was used [18]. Maternal venous blood samples were analysed for specific IgE against 13 common respiratory and food allergens. Calculation was performed by means of a standard curve that was obtained by RAST with a dilution series of a chimeric monoclonal IgE antibody against the major allergen Der p 2 and Sepharose-coupled recombinant Der p 2 [19].

In order to collect venous blood of the infants, home visits were made at 2 years post-partum. Infants' venous blood samples were analysed for specific IgE against hen's eggs, cow's milk, peanuts, birch, grass pollen, cat, dog and mite using RAST as described earlier [18]. The detection limit for total and specific IgE was 0.50 and $0.10 \mathrm{IU} / \mathrm{mL}$, respectively.

\section{Definition of maternal allergic history and maternal sensitization}

A positive maternal allergic history was defined if, in her self-reported questionnaire, the mother positively confirmed that a physician had at least once diagnosed asthma, eczema, allergy for house dust mite/pets or allergic rhinoconjunctivitis (such as hayfever).

Maternal sensitization was considered as present if serum-specific IgE against one or more of the tested inhalant or food allergens was positive ( $>0.3 \mathrm{IU} / \mathrm{mL}$ ). High total IgE for mothers was arbitrarily defined as total IgE level > $100 \mathrm{IU} / \mathrm{mL}$.

\section{Definition of infant's atopic manifestations and infant's allergic sensitization}

Information on the development of eczema (based on ISAAC questions) was obtained in the 3-, 7- and 12month questionnaires. Parents were asked; 'has your child ever had an itchy rash that was coming and going in the past months'? If this question was answered affirmatively, infants were defined as having developed eczema in the first 2 years of life. Cases of only diaper rash, rash around the eyes and/or scalp scaling were excluded. 'Ever wheezing' was defined as parentally reported presence of wheezing, with at least one attack, in the 7-, 12- or 24month post-partum questionnaires. Infants were considered to be sensitized if specific serum IgE-levels were
$>0.3 \mathrm{IU} / \mathrm{mL}$ against one or more of the tested food or inhalant allergens. High total IgE for infants was arbitrarily defined as total IgE level $>10 \mathrm{IU} / \mathrm{mL}$.

\section{Atopic dermatitis by UK Working Party criteria}

To specify eczema reported by parents as described above, we defined atopic dermatitis according to UK Working Party criteria [20] for all infants who were visited at home at age 2 years. The probability of the presence of atopic dermatitis was derived from the presence of four clinical symptoms: (1) presence of itchy rash (PIR, coded as $0=$ absent, 1 = present), (2) history of flexural dermatitis (HFD, $0=$ absent, 1 = present), (3) visible flexural dermatitis (VFD, $0=$ absent, 1 = present) and (4) onset before age of 2 years $(\mathrm{OB} 2,0=$ absent, $1=$ present). The UK working party (UK-WP) probability score of atopic dermatitis (AD) is then computed as: probability $\mathrm{AD}=$ odds $(\mathrm{AD}) /[$ odds $(\mathrm{AD})+1]$, where odds $(\mathrm{AD})=\exp [-4.36+1.84(\mathrm{HFD})+$ 3.46(OB2) +2.09 (VFD) + 1.71(PIR)] [20]. In this study, infants with a UK-WP probability score of atopic dermatitis $(\mathrm{AD})>0.9$ were regarded as infants with 'probable presence of atopic dermatitis'.

\section{Statistical analysis}

Extreme values of concentrations of cytokines and sCD14 were not excluded as these did not influence our results. The mean values of concentrations of cytokines and sCD14 were compared between groups using analysis of variance (ANOVA). To assess the association between cytokines and infant's atopic manifestations, we conducted a multivariate logistic regression analysis in order to adjust for possible confounders ('recruitment group' (conventional vs. alternative), maternal age (years), maternal allergic history (yes/no), number of older siblings (no siblings, one, two or more), season of breast milk collection (winter 2002-2003, spring 2003, summer 2003), use of probiotics in capsules or yoghurts at 1 month postpartum (yes/no), maternal infection in week of breast milk collection (yes; that is, vomiting, diarrhoea, having a cold, sore throat, mastitis, fever or urinary tract infection), time-interval between birth and breast milk collection (in days) and total storage time in freezer until analysis (in days)). Based on sample sizes of previous studies [9, 14], we estimated that 300 breast milk samples were sufficient to detect differences of interest. We consider $P$-values $\leqslant 0.05$ as statistically significant. All analyses are presented for both recruitment groups (conventional and alternative cohort) together, because stratified analyses showed similar results for both groups.

\section{Results}

A total of 315 mothers donated a breast milk sample at 1 month post-partum. This subcohort consisted of $60 \%$ of 
breastfeeding mothers from the KOALA study who were visited for venous blood collection at 34-36 weeks of gestation (from October 2002 onwards). The main reasons for not donating breast milk were unsuccessful breastfeeding or logistic reasons. The characteristics of these mothers and their infants are summarized in Table 1. We could determine TGF- $\beta 1$ and sCD14 in 307 (98\%) breast milk samples, whereas IL-12 was determined in 293 (93\%) samples. No data of IL-10 in breast milk are presented as we did not detect IL-10 above the detection limit of $0.2 \mathrm{pg} / \mathrm{mL}$.

We found no difference in the mean concentrations of TGF- $\beta 1$ in breast milk between mothers with or without an allergic history (Table 2). Also, the mean concentrations of TGF- $\beta 1$ in breast milk were not different between mothers with and without allergic sensitization $(P=0.15$; Table 2) or between mothers with or without high levels of total IgE (not shown). For sCD14, we found a somewhat higher concentration in breast milk in mothers with an allergic history compared with mothers without (7.6 vs. $7.0 \mu \mathrm{g} / \mathrm{mL} ; P=0.04$ ) (Table 2). Also, we found a higher concentration of SCD14 in mothers who were sensitized compared with non-sensitized mothers (7.8 vs. $7.1 \mu \mathrm{g} / \mathrm{mL}$, $P=0.03$; Table 2). The levels of sCD14 were similar in

Table 1. Characteristics of participants (with conventional versus alternative lifestyle) with breast milk sample $(N=315)$

\begin{tabular}{|c|c|c|}
\hline & Conventional & Alternative \\
\hline & $N=146$ & $N=169$ \\
\hline Maternal age in years (mean \pm SD) & $32.4 \pm 3.3$ & $34.0 \pm 4.2$ \\
\hline $\begin{array}{l}\text { Breastfeeding duration in months } \\
\text { (mean } \pm \mathrm{SD})^{*}\end{array}$ & $4.2 \pm 3.0$ & $6.5 \pm 3.1$ \\
\hline Sex of infant (no. of boys, percentage) & $71(48.6 \%)$ & $83(49.1 \%)$ \\
\hline \multicolumn{3}{|l|}{ Infant's atopic outcome, at age 2 years } \\
\hline $\begin{array}{l}\text { Eczema by questionnaire (yes, } \\
\text { percentage) }\end{array}$ & $42(28.8 \%)$ & $51(30.2 \%)$ \\
\hline $\begin{array}{l}\text { Atopic dermatitis by UK-WP (yes, } \\
\text { percentage) }\end{array}$ & $16(11.0 \%)$ & $15(8.9 \%)$ \\
\hline Wheeze (yes, percentage) & $41(28.1 \%)$ & $42(24.9 \%)$ \\
\hline $\begin{array}{l}\text { Both eczema + wheeze (yes, } \\
\text { percentage) }\end{array}$ & $11(7.5 \%)$ & $12(7.1 \%)$ \\
\hline \multicolumn{3}{|l|}{ Cytokines and sCD14 in breast milk } \\
\hline TGF- $\beta 1$ in pg/mL (mean \pm SD) & $225.6 \pm 178.3$ & $212.5 \pm 117.8$ \\
\hline \multicolumn{3}{|l|}{$N=307^{\dagger}$} \\
\hline Range TGF- $\beta 1$ in $\mathrm{pg} / \mathrm{mL}$ & $12.0-1536.8$ & $2.0-647.9$ \\
\hline $\mathrm{IL}-10 \mathrm{in} \mathrm{pg} / \mathrm{mL}$ & $\mathrm{ND}^{\ddagger}$ & $\mathrm{ND}^{\ddagger}$ \\
\hline $\mathrm{sCD} 14$ in $\mu \mathrm{g} / \mathrm{mL}$ (mean $\pm \mathrm{SD})$ & $7.7 \pm 2.9$ & $7.1 \pm 2.2$ \\
\hline \multicolumn{3}{|l|}{$N=307^{\dagger}$} \\
\hline Range sCD14 in $\mu \mathrm{g} / \mathrm{mL}$ & $1.7-23.8$ & $2.3-20.1$ \\
\hline $\mathrm{IL}-12 \mathrm{in} \mathrm{pg} / \mathrm{mL}$ (mean $\pm \mathrm{SD}) N=293^{\dagger}$ & $10.6 \pm 6.5$ & $10.8 \pm 6.0$ \\
\hline Range IL-12 in pg/mL & $0.7-52.8$ & $1.5-51.6$ \\
\hline
\end{tabular}

*Exclusive and non-exclusive breastfeeding.

${ }^{\dagger}$ Missing due to insufficient aqueous fraction available.

${ }^{\ddagger}$ Not detectable i.e. under the detection limit of $0.2 \mathrm{pg} / \mathrm{mL}$.
Table 2. Mean concentrations of TGF- $\beta 1$, sCD14 and IL- 12 in breast milk related to maternal allergic history and specific serum IgE

\begin{tabular}{|c|c|c|c|c|c|c|}
\hline & \multicolumn{2}{|c|}{ TGF- $\beta 1$ (pg/mL) } & \multicolumn{2}{|c|}{$\mathrm{sCD} 14(\mu \mathrm{g} / \mathrm{mL})$} & \multicolumn{2}{|c|}{ IL-12 (pg/mL) } \\
\hline & $n$ & $\begin{array}{l}\text { Mean } \\
\text { (SD) }\end{array}$ & $n$ & $\begin{array}{l}\text { Mean } \\
\text { (SD) }\end{array}$ & $n$ & $\begin{array}{l}\text { Mean } \\
\text { (SD) }\end{array}$ \\
\hline \multicolumn{7}{|c|}{ Maternal allergic history } \\
\hline No & 125 & $221.1(140.1)$ & 124 & $7.0(2.4)$ & 120 & $10.3(6.2)$ \\
\hline Yes & 182 & $216.9(155.1)$ & 183 & $7.6(2.6)$ & 173 & $11.0(6.3)$ \\
\hline$P^{\dagger}$ & & 0.81 & & 0.04 & & 0.35 \\
\hline \multicolumn{7}{|c|}{ Maternal sensitization } \\
\hline No sensitization* & 164 & 207.9 (127.3) & 164 & $7.1(2.8)$ & 164 & $10.4(5.2)$ \\
\hline Sensitization & 123 & $238.1(180.2)$ & 123 & $7.8(2.4)$ & 123 & $11.1(7.4)$ \\
\hline$P^{\dagger}$ & & 0.15 & & 0.03 & & 0.35 \\
\hline
\end{tabular}

SD, standard deviation.

*Specific IgE $>0.3 \mathrm{IU} / \mathrm{mL}$ for any of the 13 measured food or inhalant allergens (missing $n=6$ ).

${ }^{\dagger} P$ value based on ANova.

mothers with high vs. low total IgE levels (7.3 vs. $7.2 \mu \mathrm{g} /$ $\mathrm{mL} ; P=0.84$; results not shown in table). Finally, we did not detect differences in the mean concentrations of IL-12 in breast milk between mothers with and without an allergic history or between sensitized and non-sensitized mothers (Table 2), nor between mothers with and without high levels of total IgE (not shown).

The results for the relationships between the concentrations of breast milk immune factors (in tertiles) and the infant's atopic outcome are presented in Table 3. The risk of infant's eczema (by questionnaires) and wheeze was not associated with breast milk levels of TGF- $\beta 1$, sCD14 and IL-12 (odds ratios show no trend over the tertiles, and 95\% confidence intervals include the value 1.0). Also, no association was present between the presence of allergic sensitization and TGF- $\beta 1$, sCD14 and IL-12 (Table 3). Neither did we find an association between high total serum IgE $(>10 \mathrm{IU} / \mathrm{mL})$ or atopic dermatitis by UK-WP criteria and TGF- $\beta 1, \mathrm{sCD} 14$ and IL- 12 (results not shown).

\section{Discussion}

In the present study, we found higher levels of sCD14 in mothers with a maternal allergic history and sensitization. No such associations between TGF- $\beta 1$ and IL- 12 in breast milk and maternal allergic status were found. None of the studied immune factors (TGF- $\beta 1$, sCD14 and IL-12) in breast milk were associated with infant's atopic outcomes.

Our first aim was to assess whether milk levels of TGF$\beta 1, \mathrm{IL}-10, \mathrm{IL}-12$ and $\mathrm{SCD} 14$ reflect the mother's allergic history. A few studies have compared the concentrations of immune factors in breast milk between atopic and nonatopic mothers. In a small study, Rigotti et al. [21] found that TGF- $\beta 1$ was significantly less in the mature milk of allergic mothers. In agreement with the present study, 
Table 3. Adjusted odds ratios for the presence of eczema and wheezing in the first 2 years of life and allergic sensitization at age 2 years, depending on the concentrations of TGF- $\beta 1$, sCD14 and IL-12 (in tertiles) in breast milk

\begin{tabular}{|c|c|c|c|c|c|c|}
\hline & \multicolumn{2}{|c|}{ Infant's eczema (by questionnaires) } & \multicolumn{2}{|c|}{ Infant's wheeze } & \multicolumn{2}{|c|}{ Infant's sensitization } \\
\hline & $n$ & aOR $(95 \% \mathrm{CI})^{\dagger}$ & $n$ & aOR $(95 \% \mathrm{CI})^{\dagger}$ & $n$ & aOR $(95 \% \mathrm{CI})^{\dagger}$ \\
\hline \multicolumn{7}{|l|}{ TGF- $\beta 1$ (pg/mL) } \\
\hline Low $_{(2.0-166.9)}$ & 30 & 1.0 (reference) & 24 & 1.0 (reference) & 17 & 1.0 (reference) \\
\hline Middle $_{(166.9-248.4)}$ & 32 & $1.14(0.59-2.10)$ & 28 & $1.21(0.61-2.93)$ & 21 & $1.19(0.52-2.74)$ \\
\hline High $_{(248.5-1536.8)}$ & 28 & $1.00(0.53-1.91)$ & 28 & $1.13(0.57-2.23)$ & 12 & $0.51(0.21-1.24)$ \\
\hline$P_{\text {for trend }}$ & & $1.00(N=299)$ & & $0.73(N=299)$ & & $0.13(N=200)$ \\
\hline \multicolumn{7}{|l|}{$\mathrm{sCD} 14(\mu \mathrm{g} / \mathrm{mL})$} \\
\hline $\operatorname{Low}_{(1.7-6.3)}$ & 29 & 1.0 (reference) & 25 & 1.0 (reference) & 16 & 1.0 (reference) \\
\hline Middle $(6.4-8.0)$ & 38 & $1.70(0.90-3.23)$ & 26 & $1.38(0.69-2.77)$ & 18 & $1.11(0.49-2.54)$ \\
\hline $\operatorname{High}_{(8.1-23.8)}$ & 26 & $1.00(0.50-2.00)$ & 32 & $1.85(0.92-3.69)$ & 17 & $1.06(0.46-2.47)$ \\
\hline$P_{\text {for trend }}$ & & $0.98(N=307)$ & & $0.08(N=307)$ & & $0.89(N=207)$ \\
\hline \multicolumn{7}{|l|}{ IL-12 (pg/mL) } \\
\hline $\operatorname{Low}_{(0.6-7.8)}$ & 24 & 1.0 (reference) & 24 & 1.0 (reference) & 18 & 1.0 (reference) \\
\hline Middle $_{(7.9-11.8)}$ & 35 & $1.60(0.83-3.11)$ & 29 & $1.35(0.68-2.69)$ & 13 & $0.77(0.32-1.89)$ \\
\hline $\operatorname{High}_{(11.9-52.8)}$ & 26 & $1.18(0.59-2.38)$ & 22 & $1.06(0.51-2.21)$ & 15 & $0.77(0.33-1.83)$ \\
\hline$P_{\text {for trend }}$ & & $0.61(N=285)$ & & $0.84(N=285)$ & & $0.54(N=190)$ \\
\hline
\end{tabular}

aOR, adjusted odds ratio.

*Sensitization is defined as specific serum IgE-levels $>0.3 \mathrm{IU} / \mathrm{mL}$ against one or more of the tested food or inhalant allergens.

${ }^{\dagger}$ From logistic regression analysis, adjusting for: recruitment group (conventional versus alternative), maternal age, maternal allergic history, number of older siblings, season of breast milk collection, maternal use of probiotics, maternal infection (during week of breast milk collection), time interval between birth and breast milk collection (in days) and total storage time in freezer until analysis (in days).

Böttcher et al. [22] reported no differences for TGF- $\beta$. In agreement with our findings, a small study found no associations between IL-12 in breast milk and a maternal atopic status [23]. Our findings of higher levels of sCD14 in mothers with a maternal allergic history $(P=0.04)$ or mothers with sensitization $(P=0.03)$ have not been reported earlier. However, the results of a German study presented a slightly higher prevalence of maternal atopic history in the upper quartile of breast milk sCD 14, directed towards borderline statistical significance $(P=0.07)$ [15]. Savilahti et al. [24] found lower levels of SCD14 in the colostrum of atopic vs. non-atopic mothers when the definition of atopy was based on a single symptom but when a more rigid definition was used, the difference disappeared. For sCD14 levels in breast milk, our results tend towards a relation with both a maternal allergic history and maternal sensitization but not with high total IgE in the mother. We speculate that disease activity (at the moment of breast milk sampling) in atopic mothers may be reflected in higher sCD14 levels. Higher levels of serum SCD14 are seen in subjects with disease activity for instance after exacerbation of asthma in children [25, 26]. However, we did not assess the asthmatic status or the presence of rhinoconjuctivitis at the moment of breast milk sampling. Alternatively, atopic vs. non-atopic mothers could differ in genetic constitution, leading to different sCD14 levels. Guerra et al. [27] found that sCD14 levels in milk differed significantly by CD14/ - 1619 and CD14/ - 550 genotypes and haplotypes. The biologic relevance for the infant of such small differences in sCD14 concentrations between atopic and non-atopic mothers can be argued.

Our second aim was to assess whether TGF- $\beta 1$, IL-10, IL-12 and sCD14 levels in breast milk were associated with the development of infant's atopic manifestations. We consider infant's eczema (by questionnaire, adapted from ISAAC) and sensitization as separate outcome parameters instead of atopic eczema because sensitized infants do not necessarily show symptoms of eczema or vice versa [28]. Consequently, we use the term eczema instead of atopic eczema. However, we use the term 'atopic dermatitis' for infants fulfilling the UK-WP criteria according to the criteria of Williams et al. [20]. If we used more stringent criteria for wheeze such as proposed by others [29], the number of cases was too small for a multivariate analysis.

We found no associations between TGF- $\beta 1, \mathrm{sCD} 14$ and IL-12 and infants' atopic outcomes. The Infant Immune Study (Tucson, Arizona) found a statistically significant association between low levels of TGF- $\beta 1$ and wheeze at the age of 1 year [9]. Furthermore, the British study of Jones et al. [14] found that low levels of breast milk sCD14 were associated with a diagnosis of eczema in 6-monthold infants, irrespective of skin prick testing, in a high-risk cohort. More recently, Rothenbacher et al. [15] found a lower risk for atopic eczema for breastfed infants $(\geqslant 6$ months, sCD14 in the highest quartile) vs. less than 3 months' breastfeeding. They suggested that the beneficial 
effects of breastfeeding are supported by high levels of sCD14. By contrast, Laitinen et al. found that sCD14 tended to be higher in mature breast milk received by infants with vs. without atopic eczema with a positive skin prick test. Previous studies have investigated IL-10 [9, 22, $30-32]$, IL-12 [23, 33, 34] or TGF- $\beta 1$ [8, 9, 22, 24, 32, 35, 36] concentrations in breast milk with inconsistent results with respect to the mothers and/or infant's atopic outcomes. We speculate that three explanations may clarify these inconsistencies. First, differences in methodologies could be an explanation, e.g. the moment of breast milk sampling. It can be anticipated that cytokine concentrations are higher in colostrum than mature milk. This is not supported by a study with longitudinal human milk collection, reporting a slight change in the mean concentration of both TGF- $\beta 1$ and TGF- $\beta 2$ during the first 12 weeks of lactation, including colostrum [36]. However, this may not necessarily apply for sCD14 and IL-12. Second, the effects caused by colostral factors may no longer be valid at the infant's age of 1 month because the permeability of the gut is diminishing and the efficiency of proteolysis is enhanced [37]. In addition, Blais et al. [38] found that $\mathrm{sCD} 14$ in breast milk is more susceptible to the infant's pancreatin digestion vs. pepsin digestion by in vitro experiments, suggesting decreased activity of sCD14 in the LPS-rich environment of the distal bowel. Third, the use of different ELISA kits may explain inconsistent results between studies [23]. It was noted in two studies that the use of ELISA assays of REDD Systems did not detect IL-12 in breast milk [33, 34]. We were also unable to detect IL-12 in breast milk with that same ELISA. However, using a high-sensitivity kit (Biosource Int.), we detected IL-12 in our breast milk samples. Previously, IL-12 was also found in breast milk samples in a study using ELISA assays of Pharmingen (San Diego, CA, USA) [23].

A limitation of our study was a restriction of complete standardization of breast milk collection. Different modes of pumping and individual variation in pumping techniques could have led to variation of the measured immune factors. The strength of this study was the number of breast milk samples available as only a few studies measured SCD14 or cytokines in a large amount of breast milk samples.

In summary, we found higher concentrations of sCD14 in breast milk in mothers with a positive allergic history and mothers with allergic sensitization but not for high total IgE. Taking together the results of the present study and other studies, we conclude that there may be no consistent effect on inter-individual differences of TGF- $\beta 1$, sCD14 and IL-12 in breast milk and the infant's atopic outcomes. Therefore, the search for the modifying effects of factors present in breast milk on the development of atopic manifestations should continue.

\section{Acknowledgements}

This study was supported by a grant from the Netherlands Organisation for Health Research and Development (Zon$\mathrm{Mw}$ ), programme of Innovative Prevention Research (Prevention Program 1, no. 210-00-090).

We thank Nicole Custers (assistance in breast milk collection), Chantal Delnoy/Brigitte Winants/Karen Groot (blood collection), Cobie Martens/Willeke Hendrikx (assistance data collection questionnaires), Astrid van Leeuwen (Sanquin, IgE determination), Mia Vaessen (assistance in ELISA) and all mothers and their infants participating in the KOALA study.

\section{References}

1 Worldwide variation in prevalence of symptoms of asthma, allergic rhinoconjunctivitis and atopic eczema: ISAAC. The international study of Asthma and Allergies in childhood (ISAAC) steering committee. Lancet 1998; 351:1225-32.

2 Hanson LA, Korotkova M, Haversen L et al. Breast-feeding, a complex support system for the offspring. Pediatr Int 2002; 44:347-52.

3 Wijga AH, van Houwelingen AC, Kerkhof M et al. Breast milk fatty acids and allergic disease in preschool children: the prevention and incidence of Asthma and Mite Allergy birth cohort study. J Allergy Clin Immunol 2006; 117:440-7.

4 Newburg DS. Innate immunity and human milk. J Nutr 2005; 135:1308-12.

5 Akbari 0, Stock P, DeKruyff RH, Umetsu DT. Role of regulatory T cells in allergy and asthma. Curr Opin Immunol 2003; 15: 627-33.

6 Damoiseaux J. Regulatory T cells: back to the future. Neth J Med 2006; 64:4-9.

7 Romagnani S. Immunologic influences on allergy and the TH1/ TH2 balance. J Allergy Clin Immunol 2004; 113:395-400.

8 Saito S, Yoshida M, Ichijo M, Ishizaka S, Tsujii T. Transforming growth factor-beta (TGF-beta) in human milk. Clin Exp Immunol 1993; 94:220-4.

9 Oddy WH, Halonen M, Martinez FD et al. TGF-beta in human milk is associated with wheeze in infancy. J Allergy Clin Immunol 2003; 112:723-8.

10 Frey EA, Miller DS, Jahr TG et al. Soluble CD14 participates in the response of cells to lipopolysaccharide. J Exp Med 1992; 176: 1665-71.

11 Camporota L. Interleukin-12 and the development of atopy. Clin Exp Allergy 2001; 31:1481-4.

12 Wright SD, Ramos RA, Tobias PS, Ulevitch RJ, Mathison JC. CD14, a receptor for complexes of lipopolysaccharide (LPS) and LPS binding protein. Science 1990; 249:1431-3.

13 Miyake K. Innate recognition of lipopolysaccharide by CD14 and toll-like receptor 4-MD-2: unique roles for MD-2. Int Immunopharmacol 2003; 3:119-28.

14 Jones CA, Holloway JA, Popplewell EJ et al. Reduced soluble CD14 levels in amniotic fluid and breast milk are associated with the subsequent development of atopy, eczema, or both. J Allergy Clin Immunol 2002; 109:858-66.

15 Rothenbacher D, Weyermann M, Beermann C, Brenner H. Breastfeeding, soluble CD14 concentration in breast milk and 
risk of atopic dermatitis and asthma in early childhood: birth cohort study. Clin Exp Allergy 2005; 35:1014-21.

16 Kummeling I, Thijs C, Penders J et al. Etiology of atopy in infancy: the KOALA birth Cohort study. Pediatr Allergy Immunol 2005; 16:679-84.

17 Stallman PJ, Aalberse RC. Estimation of basophil-bound IgE by quantitative immunofluorescence microscopy. Int Arch Allergy Appl Immunol 1977; 54:9-18.

18 Akkerdaas JH, Wensing M, Asero R et al. IgE binding to pepsindigested food extracts. Int Arch Allergy Immunol 2005; 138: 203-8.

19 Schuurman J, Perdok GJ, Lourens TE, Parren PW, Chapman MD, Aalberse RC. Production of a mouse/human chimeric IgE monoclonal antibody to the house dust mite allergen Der p 2 and its use for the absolute quantification of allergen-specific IgE. J Allergy Clin Immunol 1997; 99:545-50.

20 Williams HC, Burney PG, Hay RJ et al. The U. K. Working Party's Diagnostic Criteria for Atopic Dermatitis. I. Derivation of a minimum set of discriminators for atopic dermatitis. $\mathrm{Br}$ J Dermatol 1994; 131:383-96.

21 Rigotti E, Piacentini GL, Ress M, Pigozzi R, Boner AL, Peroni DG. Transforming growth factor-beta and interleukin-10 in breast milk and development of atopic diseases in infants. Clin Exp Allergy 2006; 36:614-8.

22 Bottcher MF, Jenmalm MC, Garofalo RP, Bjorksten B. Cytokines in breast milk from allergic and nonallergic mothers. Pediatr Res 2000; 47:157-62.

23 Bryan DL, Hawkes JS, Gibson RA. Interleukin-12 in human milk. Pediatr Res 1999; 45:858-9.

24 Savilahti E, Siltanen M, Kajosaari M, Vaarala 0, Saarinen KM. IgA antibodies, TGF-beta1 and -beta2, and soluble CD14 in the colostrum and development of atopy by age 4. Pediatr Res 2005; 58:1300-5.

25 Garty BZ, Monselise Y, Nitzan M. Soluble CD14 in children with status asthmaticus. Isr Med Assoc $J$ 2000; 2:104-7.

26 Kusunoki T, Nakahata T, Miyanomae T, Inoue Y. Possible dual effect of CD14 molecule on atopy. Am J Respir Crit Care Med 2002; 165:551-2; author reply 552.
27 Guerra S, Carla Lohman I, LeVan TD, Wright AL, Martinez FD, Halonen M. The differential effect of genetic variation on soluble CD14 levels in human plasma and milk. Am J Reprod Immunol 2004; 52:204-11.

28 Kusel MM, Holt PG, de Klerk N, Sly PD. Support for 2 variants of eczema. J Allergy Clinical Immunol 2005; 116: 1067-72.

29 Martinez FD. Development of wheezing disorders and asthma in preschool children. Pediatrics 2002; 109 (Suppl.): 362-7.

30 Rudloff S, Niehues T, Rutsch M, Kunz C, Schroten H. Inflammation markers and cytokines in breast milk of atopic and nonatopic women. Allergy 1999; 54:206-11.

31 Garofalo R, Chheda S, Mei F et al. Interleukin-10 in human milk. Pediatr Res 1995; 37 (Part 1):444-9.

32 Ogawa J, Sasahara A, Yoshida T et al. Role of transforming growth factor-beta in breast milk for initiation of IgA production in newborn infants. Early Hum Dev 2004; 77:67-75.

33 Srivastava MD, Srivastava A, Brouhard B, Saneto R, Groh-Wargo S, Kubit J. Cytokines in human milk. Res Commun Mol Pathol Pharmacol 1996; 93:263-87.

34 Sone S, Tsutsumi H, Takeuchi R et al. Enhanced cytokine production by milk macrophages following infection with respiratory syncytial virus. J Leukoc Biol 1997; 61:630-6.

35 Kalliomaki M, Ouwehand A, Arvilommi H, Kero P, Isolauri E. Transforming growth factor-beta in breast milk: a potential regulator of atopic disease at an early age. J Allergy Clin Immunol 1999; 104:1251-7.

36 Hawkes JS, Bryan DL, James MJ, Gibson RA. Cytokines (IL-1beta, IL-6, TNF-alpha, TGF-beta1, and TGF-beta2) and prostaglandin E2 in human milk during the first three months postpartum. Pediatr Res 1999; 46:194-9.

37 Goldman AS, Chheda S, Garofalo R. Evolution of immunologic functions of the mammary gland and the postnatal development of immunity. Pediatr Res 1998; 43:155-62.

38 Blais DR, Harrold J, Altosaar I. Killing the messenger in the nick of time: persistence of breast milk sCD14 in the neonatal gastrointestinal tract. Pediatr Res 2006; 59:371-6. 